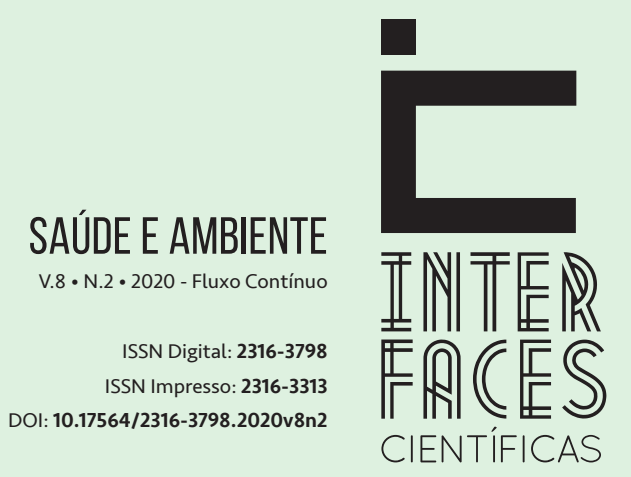

\section{COVID-19 PANDEMIC IN BRAZIL: NO COMPLIANCE OF POLICIES AND AGGRAVATING ELEMENTS FOR VULNERABLE POPULATION AND ECOSYSTEMS}

PANDEMIA DE COVID-19 NO BRASIL: O NÃO CUMPRIMENTODE POLITICAS E ELEMENTOS AGRAVANTES PARA POPULACOÕES VULNERÁVEIS E ECOSSISTEMAS

PANDEMIA DE COVID-19 EN BRASIL: INCUMPLIMIENTO DE POLITICAS Y AGRAVANTES PARA POBLACIONES Y ECOSISTEMAS VULNERABLES
Fabio Leandro da Silva ${ }^{1}$ Allan do Amaral Micheleti ${ }^{2}$ Ângela Terumi Fushita ${ }^{3}$ Marcela Bianchessi da Cunha Santino ${ }^{4}$ Irineu Bianchini Júnior ${ }^{5}$

\section{ABSTRACT}

We aim to stand out aggravating factors that can compromise the COVID-19 pandemic in Brazil and the eventual risks for vulnerable people and ecosystems, as well as, suggest future actions that need to be adopted. A theoretical reflection was conducted, considering references available on Scopus and PubMed. Brazilian public policies, adverse effects of COVID-19 pandemic, and future actions were highlighted. We demonstrated that proper water, sanitation, and hygiene $(\mathrm{WaSH})$ are essential to face the pandemic, however, more than 39 million of Brazilians do not have access to basic sanitation and clean drinking-water. There is a possibility of the novel coronavirus be transmitted by untreated wastewater, being necessary to promote actions that improve sanitation, reduce ecosystems threat, and poverty.

\section{KEYWORDS}

Public Health; Coronavirus; Basic Sanitation; Water Quality. 


\section{RESUMO}

Visamos destacar os fatores agravantes que podem comprometer a pandemia de COVID-19 no Brasil e os eventuais riscos para pessoas vulneráveis e ecossistemas, bem como, sugerir ações futuras a serem adotadas. Foi realizada uma reflexão teórica, considerando referências disponíveis no Scopus e PubMed. Políticas públicas brasileiras, efeitos adversos da pandemia COVID-19 e ações futuras foram destacados. Demonstramos que água, saneamento e higiene adequados (WaSH) são essenciais para enfrentar a pandemia, no entanto, mais de 39 milhões de brasileiros não têm acesso a saneamento básico e água potável. Existe a possibilidade do novo coronavírus ser transmitido por esgoto não tratado, sendo necessário promover ações que melhorem o saneamento, reduzam a ameaça aos ecossistemas e a pobreza.

\section{PALAVRAS-CHAVE}

Saúde Coletiva; Coronavírus; Saneamento Básico; Qualidade da Água.

\section{RESUMEN}

Nuestro objetivo es destacar los factores agravantes que pueden comprometer la pandemia de COVID-19 en Brasil y los posibles riesgos para las personas y ecosistemas vulnerables, así como sugerir acciones futuras a tomar. Se realizó una reflexión teórica, considerando las referencias disponibles en Scopus y PubMed. Se destacaron las políticas públicas brasileñas, los efectos adversos de la pandemia COVID-19 y las acciones futuras. Demostramos que el água, el saneamiento y la higiene adecuados $(\mathrm{WaSH})$ son esenciales para enfrentar la pandemia, sin embargo, más de 39 millones de brasileños no tienen acceso a saneamiento básico y água potable. Existe la posibilidad de que el nuevo coronavirus se transmita por águas residuales sin tratamento, y es necesario impulsar acciones que mejoren el saneamiento, reduzcan la amenaza a los ecosistemas y la pobreza.

\section{PALABRAS CLAVE}

Salud Publica; Coronavirus; Saneamiento Básico; Calidad del água. 


\section{INTRODUCTION}

SARS-CoV-2 is the novel coronavirus, responsible for causes the COVID-19 disease (LANA et al., 2020). Because of the severity and spread on a global scale, the World Health Organization characterized the COVID-19 as pandemic and reinforced its impact on public health (WHO, 2020). This pandemic has been causing many deaths and negatively affecting the economy (BARBIER; BURGESS, 2020).

The novel coronavirus survives in different types of surfaces for many hours; naturally, hygiene contributes to infection and transmission reduction (BHUSARE et al., 2020). Proper sanitation and water quality are essential conditions that can contribute to pandemic control, their lack implies in healthcare needs commitment (EVERARD et al., 2020; HELLER et al., 2020). Cough etiquette, hand hygiene, facial mask use are indispensable for the reduction of the SARS-CoV-2 contamination risk (SILVA, 2020). In this sense, the investment in the water quality improvement and sanitation play an important role in COVID-19 pandemic control, reducing new infections on account of the hygiene measures.

Personal hygiene is an effective strategy to face pandemic, especially in large cities, marked by the social and spatial exclusion of lower socio-economic classes (e.g. residents from a slum, urban poor areas, homeless) that do not have access to safety water, sanitation, and hygiene (WaSH) conditions, factors that increase the disease propagation and put vulnerable people in risk (DAS et al., 2020). Beyond that, there are people without minimum conditions to stay in self-quarantine, given the no household toilet and the need to supply sanitation needs out of their houses (CARUSO; FREEMAN, 2020).

Governments are facing unprecedented challenges, the healthcare disparities, poverty, and lack of sanitation contribute to the emergency of the COVID-19 in middle and low incoming countries (ANSER et al., 2020). In Brazil, the pandemic is aggravating by overloaded health system risk, due to elderly aged population proportion, lack of hospital bed, and a high number of inhabitants per hospital bed (ALMEIDA et al., 2020). Besides that, socio-spatial inequalities have been historically determining, implying in healthcare access difficulties and unsatisfactory WaSH, leaving in inappropriate conditions the vulnerable people from slums and conferring barriers to social isolation (LIMA et al., 2020; TRAVASSOS et al., 2020; WERNECK; CARVALHO, 2020).

The lockdown contributes to reduce the impacts of business and commercial activities and improve water quality due to substances input decrease, an effect of COVID-19 pandemic on hydric resources (YUNUS et al., 2020). Furthermore, the water cycle (source, distribution, use, wastewater) is facing modifications due to pandemic stress on hydric subsystems, promoted by behavioral changes and the increasing demand of the "stay at home" (POCH et al., 2020).

The primary route for the new coronavirus transmission is respiratory (WU et al., 2020), although, fecal-oral via is a potential pathway for SARS-CoV-2 transmission, due to the presence of the new coronavirus' RNA for prolonged periods in fecal samples and their replication in the gastrointestinal system (YANG; TU, 2020). Occasionally, SARS-CoV-2 is detected in urine (JONES et al., 2020). Also, SARS-CoV-2 was identified in waters systems highly impacted by sewage input, which emphasizes the need to consider the dissemination in localities marked by precarious sanitation (GUERRERO-LATORRE et al., 2020). 
So, considering above scenario, is very clear how connected are the COVID-19 pandemic and hydric resources management, which in turn is directly related to basic sanitation. We conducted a reflexive analysis, considering available references from Scopus and US National Library of Medicine (PubMed) bases and public policies, aiming to obtain information about aggravating elements in Brazil related to COVID-19 pandemic facing, possible adverse effects of the pandemic for ecosystems and signaling future actions that need to be adopted.

\section{HYDRIC RESOURCES AND BASIC SANITATION POLICIES IN BRAZIL: AGGRAVATING FACTORS IN COVID-19 PANDEMIC FACING}

Brazil has specific National Policies for Hydric Resources (Law 9,443/97) and Sanitation (Law 11,445/07). The first one (BRASIL, 1997) establishes the need to assure water quality and availability for future generations attending adequate standards. The hydric resources are subject to a plan that considers the watershed and the priorities for water use, as well as classify the water in classes to reduce pollution costs. The granting regime is directly associated with sanitation, due to qualitative and quantitative water use. Resources from water charge can be applied in sanitation infrastructure, according to the hydrographic basins plan.

The basic sanitation policy (BRASIL, 2007) brings basic elements, being sanitation, a universal right related to public health and natural resources maintenance. Hydric resources protection and regional characteristics consideration are premises, but the hydric resources do not integrate basic sanitation and the dilution and the sewage disposal are regulated by the National Hydric Resources Policy. The administrative levels must to attend targets. Health and environmental indicators are component of the planning actions.

Thus, the normative apparatus demonstrates the Brazilian population right about WaSH. Direct connections with health are established, in this sense, water quality and basic sanitation are vital for public health, a situation also observed in the Sustainable Development Goals. The COVID-19 seriously influences the health at the regional level and the dissemination is linked to government policies (SOUSA JÚNIOR et al., 2020). Many Brazilians do not have their rights ensured, as provided for by the policies, a situation that contributes to COVID-19 spread.

Data from the National Sanitation Information System from 2018, reveals that 39.4 million of Brazilians do not have treated water supply, $74.5 \%$ of sewage is collected, but only $46.3 \%$ receive adequate treatment (SNIS, 2020). Indeed, exists a negative correlation between COVID-19 cases and sewage treatment in Brazil, also is possible to observe that the regions with higher incidence and mortality rates (North and Northeast) present the low values for sanitation rates (SILVA et al., 2020).

Human contamination by the novel coronavirus can occur due to domestic sewage input into urban rivers, especially during the COVID-19 peak in infection (GUERRERO-LATORRE et al., 2020). All the waste management phases (i.e. packing and delivery; withdrawal; transport; and treatment) represent potential exposition risks for contamination due to SARS-CoV-2 persistence in surfaces 
(DI MARIA et al., 2020). Because of the many pathways of the SARS-CoV-2 spread, the virus can be transmitted in water systems, main those that receive untreated wastewater from hospitals and communities, that play a pivotal role of the potential vehicle for contamination (ADELODUN et al., 2020). The sewage sludge is a reservoir for the novel coronavirus due to the organic matter that can support the virus and the potential risk of transmission (YANG et al., 2020).

A small number of severe dysfunctions in gastrointestinal systems was observed $(11 \pm 2 \%)$ among contaminated people, the SARS-CoV-2 transmission via feces (viral load $=8.0 \times 10^{9} \mathrm{gc} /$ person $/$ day) and contaminated water is low (JONES et al., 2020), but is not null and can be higher in developing countries, because of sanitation issues.

The emergency imposed by the COVID-19 confers a new challenge for waste management, given the need for a process that damages the lipid envelop of the virus, resulting in its non-viability and conferring contamination' risks minimization (DI MARIA et al., 2020). Changes result in impacts on wastewater collection and treatment, worth to be mentioned flow reduction due to sewage sludge, as well as, potential harmful pharmaceutical products input in water systems and the presence of the novel coronavirus in municipality wastewaters (POCH et al., 2020). The SARS-CoV-2 transmission via feces will happen if the viable virus persists in the environment, conferring chances to infect an individual, who ingests a sufficient oral infective dose (ODIH et al., 2020).

The wastewater surveillance must consider the local context for solutions formulation, furthermore, it represents a tool for public health and auxiliaries in the management of the COVID-19 pandemic (STREET et al., 2020). Analysis of wastewater provides a fast answer in "real-time" in a determined geographic region, providing useful data for decision-making due to the snapshot obtained for a locality, as is usual for drug policies (LANCASTER; RHODES, 2020). The environmental monitoring in Brazilian watersheds can introduce this information in agencies routine, generating useful data for decision-makers and health surveillance, and emerging "hot spots" can be identified.

The virus is excreted by (a)symptomatic people and this explains the coronavirus presence in wastewater, although, the SARS-CoV-2 viability and the fecal-oral transmission need more efforts to become clear (LODDER; RODA HUSMAN, 2020). The patients' fecal samples can test positive for SARS-CoV-RNA for 27.9 days (WU et al., 2020). High levels of contaminated people imply in higher viral charge in water and wastewater systems, favoring the spread of disease (GORMLEY et al., 2020).

Hydric vehiculation diseases (e.g. diarrhea, hepatitis) increase due to poor WaSH, aggravating in poor areas, and emerge as a public health problem (DAS et al., 2020). In this context, exists a possibility of fecal-oral transmission of COVID-19, a situation that varies according to sewage and water treatment (SILVA et al., 2020). Nowadays, the shreds of evidence of the novel coronavirus presence and transmission in contaminated waters are scarce, but massive investigations are necessary with the employment of robust methods (LA ROSA et al., 2020).

Water quality maintenance and proper sanitation confers benefits for people and can contribute to the prevention of SARS-CoV-2 transmission, policies must assure that adequate compliance of wastewater discharge during the pandemic of COVID-19, including surveillance in rural areas and small villages (ADELODUN et al., 2020). The use of contaminated water for consumption and cleaning 
of surfaces confers risks of COVID-19 transmission due to fecal-oral via (HELLER et al., 2020). Part of the Brazilian population is at risk due to water quality loss and precarious basic sanitation, water pollution by untreated domestic sewage may contribute to COVID-19 spread.

The WaSH compromising potentializes the risks of contamination and mortality can increase among the vulnerable population (DAS et al., 2020). Handwashing reduces infection, but improper sanitation infrastructure compromises vulnerable people and inhibits such practice (COETZEE; KAGEE, 2020).

\section{COVID-19 PANDEMIC AND POSSIBLE ADVERSE EFFECTS FOR ECOSYSTEMS}

An alternative is the use of hand sanitizer, but is it a secure option? Yes, it is! Hands hygiene contributes to the non-occurrence of contamination (SILVA, 2020). However, excessive alcohol sanitizer use contributes to skin disorders due to permeability alteration, irritation, and roughness; as well as, confers adverse impacts for ecosystems and associated biota (MAHMOOD et al., 2020).

Interactions involving the novel coronavirus and aquatic microorganisms need to be explored, in addition to the virus dynamics in the aquatic systems with different conditions (WARTECKI; RZYMSKI, 2020). Lately, a large variety of antimicrobial therapies has been applied around the world during the COVID-19 pandemic, this situation is a troubling factor due to sanitation issues and, consequently, antimicrobial resistance, reinforcing the importance of public policies (ANTIMICROBIAL, 2020).

The COVID-19 pandemic directly affects the sustainable development goals, especially in developing countries, which need to look for mechanisms to the progress of those goals and inhibition of perverse incentives (BARBIER; BURGESS, 2020), generating adverse effects to natural ecosystems and biota. The novel coronavirus does not discriminate people by social class, however, in slum areas the contamination is accelerated due to undesirable conditions of WaSH (ANSER et al., 2020). The "environment risk" is associated with changes in land use cover, anthropogenic activities and their relation with diseases spread, mainly due to the influence on "animal-human" interaction, an important trigger for zoonosis emergency (VENTURA et al., 2020). In this sense, we can infer that changes in land use cover in watersheds and biodiversity loss generate risks for zoonoses emergence.

There is no evidence that SARS-CoV-2 infect aquatic animals and, the biota does not play an epidemiological role, but the pandemic period may affect livelihoods and food obtainment of the population (BONDAD-REANTASO et al., 2020). The degradation of ecosystems contributes to reducing the barriers between society and biota, because of the ecosystem services of regulation, increasing zoonotic diseases, consequently, ecosystems restoration can be listed as a strategy to regulate zoonotic disease (EVERARD et al., 2020). Furthermore, the intense use of substances (e.g. disinfectants, sanitizers, antibiotics) triggers adverse effects on microbiomes, potentializing new "threats" (SINGH, 2020).

The actual pandemic is producing the amount of waste that need to be managed and the less eco-friendly socio-cultural changes in society (KALINA; TILLEY, 2020). Water monitoring and water forecasting need to be a part of planning, water allocation must prioritize areas marked by high risks of infection and consider the consequences of climate change (ARMITAGE; NELLUMS, 2020). 
The vulnerability is linked to several factors (e.g. policies responses; sociocultural, sociohistorical, and sociopolitical ruptures) that reinforce or create situations related to people marginalization, the COVID-19 endures such situation (AHMAD et al., 2020).

\section{FUTURE ACTIONS}

The delay in the response to the COVID-19 pandemic in Brazil by public authorities magnified the problems, including sanitation and socioeconomic problems (GÓMEZ; FAVORITO, 2020). Viral material discharge in aquatic systems has been occurring in areas with inadequate sanitation, factor that may potentialize contamination risk if the novel coronavirus is viable (WARTECKI; RZYMSKI, 2020).

The address of polices for zoonotic threats and ecosystem degradation reversion is necessary (EVERARD et al., 2020). Adequate coordination needs to involve the governance, all complexity must to be managed according to the different levels, from State to municipalities, actions must be congruent (FREITAS et al., 2020). There is a need to understand the survival of SARS-CoV-2 in feces, a situation that provides bases for the determination of environmental transmission potential (JONES et al., 2020).

Considering the SARS-CoV-2 persistence and the waste generated by contaminated people, is necessary the management of waste and material from quarantine and health centers, involving multidisciplinary groups and stakeholders (DI MARIA et al., 2020). The derivation of wastewater from health care and the provision of a proper treatment, can support in virus removal (ADELODUN et al., 2020). Sanitation improvements are essential for public health (CARUSO; FREEMAN, 2020). Brazilian actions must focus on a vulnerable population and provide proper sanitation.

The regional level is characterized by asymmetries (SOUSA JÚNIOR et al., 2020). Geographical information and spatial analysis contribute to decision-making and planning, because of the understanding of the COVID-19 evolution and the correlation with socioenvironmental variables (FRANCH-PARDO et al., 2020).

Territory adoption as an analytical unit contributes to the improvement of action formulation and sociocultural context comprehension, as well as best technologies identification for sanitation and decision-making process optimization (QUEIROZ et al., 2020). Nowadays, the COVID-19 crisis in Brazil is aggravating by difficulties in Brazilian State response and arrangement; profound socio-spatial inequalities; and political polarization and conflicts (LIMA et al., 2020). Wastewater-based epidemiology must to be considered, once SARS-CoV-2 was detected in untreated wastewater, it allows to estimate the infected population in the watershed, proving the importance of wastewater monitoring (AHMED et al., 2020).

Also, is essential and priority to: (i) create planning committees in informal slum/settlements; (ii) moratorium on evictions and additional lands for health emergencies; (iii) provision of financial to support poor people; (iv) communitarian health workers deployment to auxiliary to support the population and help in health surveillance; (v) the establishment of actions to meet Sphere Humanitarian standards for WaSH; (vi) food assistance; (vii) coordinated strategies for solid waste collection; and (viii) plans for mobility and health care (CORBURN et al., 2020). Design of policies for prevention, resources destinations for prevention, consider climate change and, reduce poverty (ANSER et al., 2020). 
Sometimes, social distancing configures a challenge due to settlements proximity and demographic density (GIBSON; RUSH, 2020). The government needs to promote actions to reinforce facial mask use, hygiene importance, and cough etiquette (SILVA, 2020).

COVID-19 pandemic is a public health issue, multi-sectorial approaches need to improve health conditions, children suffer one of the major negative effects because of services inequalities (MUSHI; SHAO, 2020). Policies post-pandemic must ensure socio-economic support and focus on achieving the Sustainable Development Goals (BARBIER; BURGESS, 2020). Collaborative research with funding agencies and the wastewater industry is necessary for biosafety (BIVINS et al., 2020).

\section{FINAL REMARKS}

We have presented aggravating elements for the COVID-19 facing In Brazil. Brazilian policies related to hydric resources and basic sanitation direct impact on public health, but the population rights are not fully attempted. More than 39 million people do not have access to their right to treated water and basic sanitation assured, a situation that confers a new pathway for SARS-CoV-2, favoring fecal-oral transmission due to unsatisfactory WaSH conditions. The situation is worse in a slum and precarious settlements; besides the need for more evidence, untreated sewage may contribute to COVID-19 spread.

The substances/medicine related to the COVID-19 pandemic are possible threats to the ecosystems health, main microbial communities, and the natural system conversion potentialize zoonoses. The Brazilian government has to revert ecosystem degradations, monitor viral material discharge in aquatic systems, promote investments and improvements of basic sanitation and water quality maintenance, consider the socioeconomic context, promote policies to reduce poverty, and involve different actors in the planning oriented to wastewater management.

\section{ACKNOWLEDGMENT}

Financial support was provided by the National Council of Technological and Scientific Development - CNPq (Process number: 158927/2018-4).

\section{REFERENCES}

ADELODUN, B. et al. Snowballing transmission of COVID-19 (SARS-CoV-2) through wastewater: Any sustainable preventive measures to curtail the scourge in low-income countries? Sci. Total Environ., v. 742, art. 140680, 2020. 
AHMAD, A. et al. What does it mean to be made vulnerable in the era of COVID-19? Lancet, v. 395, n. 10235, p. 1481-482, 2020.

AHMED, W. et al. First confirmed detection of SARS-CoV-2 in untreated wastewater in Australia: A proof of concept for the wastewater surveillance of COVID-19 in the community. Sci. Total Environ., v. 728 , art. $138764,2020$.

ALMEIDA, D. et al. Brazil's vulnerability to COVID-19 quantified by a spatial metric. Publ. Health Pract., v. 1, p. 1-2, 2020.

ANSER, M. K. et al. Does communicable diseases (including COVID-19) may increase global poverty risk? A cloud on the horizon. Environ. Res., v. 187, p. 1-13, 2020.

ANTIMICROBIAL resistance in the age of COVID-19. Nature Microbiol., v. 5, n. 6, p. 779-779, 2020.

ARMITAGE, R.; NELLUMS, L. B. Water, climate change, and COVID-19: prioritizing those in water-stressed settings. Lancet Plan. Health, v. 4, n. 5, art. e175, 2020.

BARBIER E. B.; BURGESS, J. C. Sustainability and development after COVID-19. World Develop., v. 135, p. 1-4, 2020.

BHUSARE, B. P. et al. COVID-19: Persistence, Precautions, Diagnosis and Challenges. J. Pure Appl. Microbiol., v. 1, n. 14, p. 823-829, 2020.

BIVINS, A. et al. Wastewater-Based Epidemiology: Global Collaborative to Maximize Contributions in the Fight Against COVID-19. Environ. Sci. Technol., v. 54, n. 13, p. 7754-7757, 2020.

BONDAD-REANTASO, M. G. et al. Viewpoint: SARS-CoV-2 (The Cause of COVID-19 in Humans) is not known to infect aquatic food animals nor contaminate their products. Asian Fish. Sci., v. 33, p. 74-78, 2020.

BRASIL. Lei $\mathbf{n}^{\mathbf{1 1}}$ 11.445, de 5 de janeiro de 2007. Disponível em: http://www.planalto.gov.br/ccivil_03/_ato2007-2010/2007/lei/l11445.htm. Acesso em: 15 ago. 2020.

BRASIL. Lei n’ 9.433, de 8 de janeiro de 1997. Disponível em: http://www.planalto.gov.br/ccivil_03/ LEIS/L9433.htm. Acesso em: 15 ago. 2020.

CARUSO, B. A.; FREEMAN, M. C. Shared sanitation and the spread of COVID-19: risks and next steps. Lancet Plan. Health, v. 4, n. 5, art. e173, 2020. 
COETZEE, B. J.; KAGEE, A. Structural barriers to adhering to health behaviors in the context of the COVID-19 crisis: Considerations for low- and middle-income countries. Glob. Public Health, v. 15, n. 8, p. 1093-1102, 2020.

CORBURN, J. et al. Slum Health: Arresting COVID-19 and Improving Well-Being in Urban Informal Settlements. J. Urban Health, v. 97, n. 3, p. 348-357, 2020.

DAS, A. et al. Re:(In) visible impact of inadequate WaSH Provision on COVID-19 incidences can be not be ignored in large and megacities of India. Publ. Health, v. 185, p. 34-36, 2020.

DI MARIA, F. et al. Minimization of spreading of SARS-CoV-2 via household waste produced by subjects affected by COVID-19 or in quarantine. Sci. Total Environ., v. 743, art. 140803, 2020.

EVERARD, M. et al. The role of ecosystems in mitigation and management of Covid-19 and other zoonoses. Environ. Sci. Pol., v. 111, p. 7-17, 2020.

FRANCH-PARDO, I. et al. Spatial analysis and GIS in the study of COVID-19. A review. Sci. Total Environ., v. 739, art. 140033, 2020.

FREITAS, C. M. et al. COVID-19 as a global disaster: challenges to risk governance and social vulnerability in Brazil. Amb. Soc., v. 23, art. e0115, 2020.

GIBSON, L.; RUSH, D. Novel coronavirus in Cape Town informal settlements: feasibility of using informal dwelling outlines to identify high risk areas for COVID-19 transmission from a social distancing perspective. JMIR Publ. Health Surveil, v. 6, n. 2, art. e18844, 2020.

GÓMEZ, A. M. A.; FAVORITO, L. A. The social, economic and sanitary impact of COVID-19 pandemic. International Braz. J. Urol., v. 46, p. 3-5, 2020.

GORMLEY, M. et al. COVID-19: mitigating transmission via wastewater plumbing systems. Lancet Glob. Health, v. 8, n. 5, art. e643, 2020.

GUERRERO-LATORRE, L. et al. SARS-CoV-2 in river water: Implications in low sanitation countries. Sci. Total Environ., v. 743, art. 140832, 2020.

HELLER, L. et al. COVID-19 faecal-oral transmission: Are we asking the right questions? Sci. Total Environ., v. 729, art. 138919, 2020.

JONES, D. L. et al. Shedding of SARS-CoV-2 in feces and urine and its potential role in person-to-person transmission and the environment-based spread of COVID-19. Sci. Total Environ., v. 749, art. 141364, 2020. 
KALINA, M.; TILLEY, E. “This is our next problem”: Cleaning up from the COVID-19 response. Waste Manag., v. 108, p. 202-205, 2020.

LA ROSA, G. et al. Coronavirus in water environments: Occurrence, persistence and concentration methods - A scoping review. Water Res., v. 179, 115899, 2020.

LANA, R. M. et al. Emergência do novo coronavírus (SARS-CoV-2) e o papel de uma vigilância nacional em saúde oportuna e efetiva. Cad. Saúde Públ., v. 36, n. 3, art. e00019620, 2020.

LANCASTER, K.; RHODES, T. Wastewater monitoring of SARS-CoV-2: lessons from illicit drug policy. Lancet Gastroenterol. Hepatol., v. 5, n. 7, p. 641-642, 2020.

LIMA, L. D. et al. Crise, condicionantes e desafios de coordenação do Estado federativo brasileiro no contexto da COVID-19. Cad. Saúde Públ., v. 36, art. e00185220, 2020.

LODDER, W.; RODA HUSMAN, A. M. SARS-CoV-2 in wastewater: potential health risk, but also data source. Lancet Gastroenterol. Hepatol., v. 5, n. 6, p. 533-534, 2020.

MAHMOOD, A. et al. COVID-19 and frequent use of hand sanitizers; human health and environmental hazards by exposure pathways. Sci. Total Environ., v. 742, art. 140561, 2020.

MUSHI, V.; SHAO, M. Tailoring of the ongoing water, sanitation and hygiene interventions for prevention and control of COVID-19. Trop. Med. Health, v. 48, n. 1, p. 47, 2020.

ODIH, E. E. et al. Could water and sanitation shortfalls exacerbate SARS-CoV-2 transmission risks? Am. J. Trop. Med. Hyg., v. 103, n. 2, p. 554-557.

POCH, M. et al. When the fourth water and digital revolution encountered COVID-19. Sci. Total Environ., v. 744, art. 140980, 2020.

QUEIROZ, J. T. M. et al. Novos pressupostos para o saneamento no controle de arboviroses no Brasil. Cad. Saúde Públ., v. 36, art. e00223719, 2020.

SILVA, F. L. Use of homemade cloth mask in the face of the pandemic by COVID-19 in Brazil. Rev. Prev. Infec. Saúde, v. 6, p. 1-7, 2020.

SILVA, R. R. et al. Coronavirus disease and basic sanitation: too early to be worried? Rev. Soc. Bras. Med. Trop., v. 53, art. e20200345, 2020. 
SINGH, A. Covid-19: disinfectants and sanitisers are changing microbiomes. BMJ, v. 370, p. 1-1, 2020.

SNIS - Sistema Nacional de Informações Sobre Saneamento -. Painel de informações sobre saneamento. Disponível em: http://www.snis.gov.br/. Acesso em: 20 ago. 2020.

SOUSA JÚNIOR, W. C. et al. COVID-19: Local/regional inequalities and impacts over critical healthcare infrastructure in Brazil. Amb. Soc., v. 23, art. e0114, 2020.

STREET, R. et al. A. Wastewater surveillance for Covid-19: An African perspective. Sci. Total Environ., v. 743, art. 140719, 2020.

TRAVASSOS, L. R. F. C. et al. The virus, the disease and the inequality. Amb. Soc., v. 23, art. e0111, 2020.

VENTURA, D. F. L. et al. Lessons from the Covid-19 pandemic: sustainability is an indispensable condition of Global Health Security. Amb. Soc., v. 23, art. e0108, 2020.

WARTECKI, A.; RZYMSKI, P. On the coronaviruses and their associations with the aquatic environment and wastewater. Water, v. 12, n. 6, 1598, 2020.

WERNECK, G. L.; CARVALHO, M. S. The COVID-19 pandemic in Brazil: chronicle of a health crisis foretold. Cad. Saúde, v. 36, e00068820, 2020.

WHO - World Health Organization -. WHO Director-General's opening remarks at the media briefing on COVID-19 - 11 March 2020. Disponível em: https://www.who.int/dg/speeches/detail/who-director-general-s-opening-remarks-at-the-media-briefing-on-covid-19---11-march-2020. Acesso em: 20 ago. 2020.

WU, Y. et al. Prolonged presence of SARS-CoV-2 viral RNA in faecal samples. Lancet Gastroenterol. Hepatol., v. 5, n. 5, p. 434-435, 2020.

YANG, L.; TU, L. Implications of gastrointestinal manifestations of COVID-19. Lancet Gastroenterol. Hepatol., v. 5, n. 7, p; 629-630, 2020.

YANG, W. et al. The potential exposure and transmission risk of SARS-CoV-2 through sludge treatment and disposal. Resour. Conserv. Recycl., v. 162, art. 105043, 2020.

YUNUS, A. P. et al. COVID-19 and surface water quality: Improved lake water quality during the lockdown. Sci. Total Environ., v. 731, art. 139012, 2020. 
1 Bacharel em Gestão e Análise Ambiental, Programa de Pós-Graduação em Ecologia e Recursos Naturais, Universidade Federal de São Carlos, São Carlos-SP. E-mail: fabioleandro@alumni.usp.br

2 Acadêmico em Enfermagem, Faculdades Anhanguera, Campus Araraquara, Araraquara-SP.

E-mail: aamicheleti@gmail.com

3 Doutora em Ecologia e Recursos Naturais; Professora da Universidade Federal do ABC - São Bernardo do CampoSP e do Programa de Pós-Graduação em Ecologia e Recursos Naturais, Universidade Federal de São Carlos, São Carlos-SP. E-mail: angela.fushita@ufabc.edu.br

4 Doutora em Ecologia e Recursos Naturais; Professora do Programa de Pós-Graduação em Ecologia e Recursos Naturais e do Departamento de Hidrobiologia (DHb), Universidade Federal de São Carlos, São Carlos-SP. E-mail: cunha_santino@ufscar.br

5 Doutor em Ecologia e Recursos Naturais; Graduado em Ciências Biológicas; Professor do Programa de Pós-Graduação em Ecologia e Recursos Naturais e do Departamento de Hidrobiologia ( $\mathrm{DHb}$ ), Universidade Federal de São Carlos, São Carlos-SP. E-mail: irineu@ufscar.br

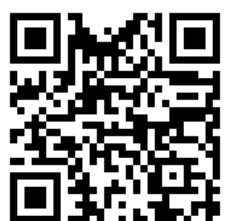

A autenticidade desse artigo pode ser conferida no site https://periodicos. set.edu.br

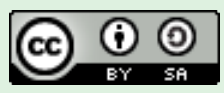

Este artigo é licenciado na modalidade acesso abertosob a Atribuição-Compartilhalgual CC BY-SA

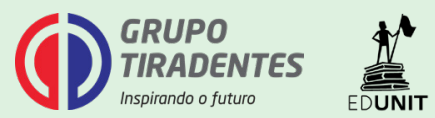

